\title{
Analytical Modeling of Geomechanical Processes in the Marginal Array Mining
}

\author{
Vladimir F. Demin*, \\ Natalida A. Nemova, Tatiana V. Demina \\ Karaganda State Tecnical University \\ 56 Mira Ave, Karaganda, 100027, The Republic of Kazakhstan \\ Siberian Federal University \\ 79 Svobodniy, Krasnoyarsk, 660041, Russia
}

Received 03.12.2014, received in revised form 11.01.2015, accepted 29.01.2015

Development of advanced technology developments on the basis of determining the stress - strain state (SSS) of the array and its influence on the parameters of the fixtures and the subsequent maintenance, is an important scientific and technical challenge of mining. During the study determined VAT around excavation: roofs, soil and sides; Rotational deformation zone bundles (cracking); stress (compression, tension, shear), offset from the lifetime (in dynamics) were considered relatively favorable, average and complex operating conditions of mine workings. Addressing the impact of mining and geological factors on the formation of zones of inelastic deformation in the country rocks around the excavation workings. Conducted investigating the stability contours of development workings in accordance with their stress-strain state depending on mining - geological factors; stress-strain state of excavation workings depending on the impact of technological factors, using the finite element method. Were defined boundary of inelastic deformation by successive loading.

Keywords: advanced technology, the stress-strain state, fixing, maintenance, mining and geological and mining-technical factors, stability workings deformation.

(c) Siberian Federal University. All rights reserved

* Corresponding author E-mail address: mcrz@mail.ru 


\title{
Аналитическое моделирование геомеханических процессов В приконтурном массиве горных выработок
}

\author{
В.Ф. Демин, Н.А. Немова, Т.В. Демина \\ Карагандинский государственный технический университет \\ Республика Казахстан, 100027, Караганда, Бульвар Мира, 56 \\ Сибирский федеральнылй университет \\ Россия, 660041, Красноярск, пр. Свободный, 79
}

\begin{abstract}
Разработка прогрессивной технологии проведения выработок на основе определения напряженно-деформированного состояния (НДС) массива и его влияния на параметры крепления и последующего поддержания является важной научно-технической задачей горного производства. В проиессе исследований определялось НДС вокруг горной выработки: кровли, почвы и боков; скорость деформачии, зона расслоений (трещинообразования); напряжения (сжатия, растяжения, касательнье), смещения от срока службы (в динамике). Рассматривались относительно благоприятные, средние и сложные условия эксплуатации горных выработок, влияние горно-геологических и горно-технических факторов на образование зон неупругих деформаций во вмещуающих породах вокруг выемочных выработок. Проводились исследования устойчивости контуров подготовительных выработок с учетом их напряженно-деформированного состояния в зависимости от горно-геологических факторов; напряженно-деформированного состояния выемочных выработок в зависимости от влияния технологических факторов с использованием метода конечных элементов. Были определены границы области неупругих деформаций методом последовательных нагружений.
\end{abstract}

Ключевые слова: прогрессивная технология, напряженно-деформированное состояние, крепление, поддержание, горно-геологические и горно-технические факторы, устойчивость выработок, деформации.

\section{Актуальность выполнения исследований}

Увеличение глубины разработки при относительно невысокой прочности пород и применении крепей с недостаточной несущей способностью и конструктивной податливостью - основные причины неудовлетворительного состояния горных выработок в Карагандинском бассейне. Важную роль в повышении эффективности производства играет решение проблемы совершенствования технологии крепления и надежного поддержания выработок. Затраты на проведение выемочных выработок достаточно велики и составляют 15-20 \% от себестоимости добычи. Устойчивое поддержание подготовительных выработок также требует значительных затрат на их ремонт как до, так и после ввода в эксплуатацию очистных забоев, которые достигают 15-20 \% от стоимости проведения горных выработок. На существующих в бассейне глубинах разработки (600-850 м) современными крепями невозможно добиться безремонтного поддержания выработок. Одним из рациональных путей улучшения состояния выработок и экономии материальных ресурсов является применение комбинированной крепи из металлоарочной и анкерной. К настоящему времени в мировой практике накоплен достаточный опыт применения технологических схем возведения анкерной крепи в горных выработках. Однако, как показывают натурные наблюдения, со- 
стояние горных выработок, особенно выемочных, не всегда удовлетворительное. Наиболее слабым звеном в решении вопросов по повышению эффективности использования анкерного крепления признана недостаточная изученность геомеханических процессов вблизи горных выработок. Одним из рациональных способов создания безопасных и эффективных условий поддержания горных выработок служит управление состоянием приконтурного породного массива.

В этой связи разработка прогрессивной технологии проведения выработок на основе определения напряженно-деформированного состояния (НДС) массива и его влияния на параметры крепления и последующего поддержания является важной научно-технической задачей горного производства.

Для проведения исследований были выбраны условия разработки с оценкой влияния следующих факторов:

- формы поперечного сечения подготовительной выработки;

- типа крепи: металлоарочная, анкерная и комбинированная;

- условий поддержания:

○ устойчивости:

- неустойчивые (трещиноватые аргиллиты);

- средней устойчивости (аргиллиты);

- устойчивые (алевролиты);

○ управляемости:

- легкоуправляемые (шахта «Казахстанская»);

- средней управляемости (шахта «Абайская»);

- трудноуправляемая (шахта «Саранская»);

○ глубине разработки

$$
\left\{\begin{array}{l}
600 \mathrm{M} \\
800 \mathrm{M} ; \\
1000 \mathrm{M} ;
\end{array}\right.
$$

○ по углу падения:

- до $10^{\circ}$,

- до $20^{\circ}$,

- до $30^{\circ}$ и более.

В процессе исследований определяли НДС вокруг горной выработки: кровли, почвы и боков; скорость деформации, зону расслоений (трещинообразования); напряжения (сжатия, растяжения, касательные), смещения от срока службы (в динамике). Рассматривались относительно благоприятные, средние и сложные условия эксплуатации горных выработок.

\section{Исследовательская часть}

Влияние горно-геологических и горно-технических факторов на образование зон неупругих деформащий во вмещающих породах вокруг выемочных выработок. Для определения условных зон неупругих деформаций использована программа «Расчет напряжения и долговечности», созданная на основе теорий упругости и кинетической прочности твердых тел [1] и позволяющая определить напряженно-деформированное состояние в рассматриваемой точке техногенного пространства, а затем установить долговечность объекта (время до разрушения)

$$
-76-
$$


и оценить устойчивость породного обнажения для последующего принятия технологических мер. Для геомеханической интерпретации результатов моделирования рассматривался конвейерный штрек 64к 10 -3 сечением 16,2 м² пласта к 10 шахты «Абайская» УД АО «АрселорМиттал Темиртау», пройденный на глубине 630-640 м (рис. 1).

На рис. 2 показаны изолинии максимальных касательных напряжений, возникающих в боковых вмещающих породах при арочной, полигональной, трапецевидной и прямоугольной формах поперечного сечения выработок.

Сравнение эпюр изолиний ослабления массива показывает, что форма выработок суще-

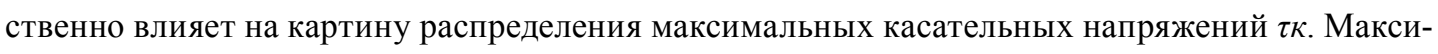
мальные концентрации ( $\tau \kappa=25 \mathrm{MПа)} \mathrm{для} \mathrm{арочной} \mathrm{и} \mathrm{полигональной} \mathrm{крепей} \mathrm{располагаются} \mathrm{на}$ почве, включая зоны примыкания к боковым стенкам выработки; для прямоугольной - там же и в кровле, а с ростом $\tau \kappa$ до $35 \mathrm{MПа} \mathrm{-} \mathrm{у} \mathrm{боковых} \mathrm{стенок} \mathrm{выработки.} \mathrm{По} \mathrm{глубине} \mathrm{распростране-}$ ния касательных напряжений вглубь массива ( $\tau \kappa=5$ и 15 МПа): для прямоугольного сечения выработки - вертикальные на 5,8 и 0,8 м, горизонтальные - на 3,5 и 0,9 м; для полигонального сечения - вертикальные на 3,8 и 0,8 м, горизонтальные - 3 и 0,9 м; для арочного сечения - вертикальные 3,3 и 0,8 м, горизонтальные - на 3 и 0,8 м. Исследования свидетельствуют, что более приемлемой для рассматриваемых условий является арочная форма поперечного сечения выработки.

На рис. 3 приведены условные зоны неупругих деформаций вблизи выработки в различные периоды времени начиная с момента обнажения пород. Анализ линий долговечности вокруг выработки показывает, что формирование условных зон неупругих деформаций начинается в почве выработки, в углу у боковой стойки, примыкающей к линии восстания пласта, и по истечении месяца охватывает всю ширину выработки, распространяясь вглубь

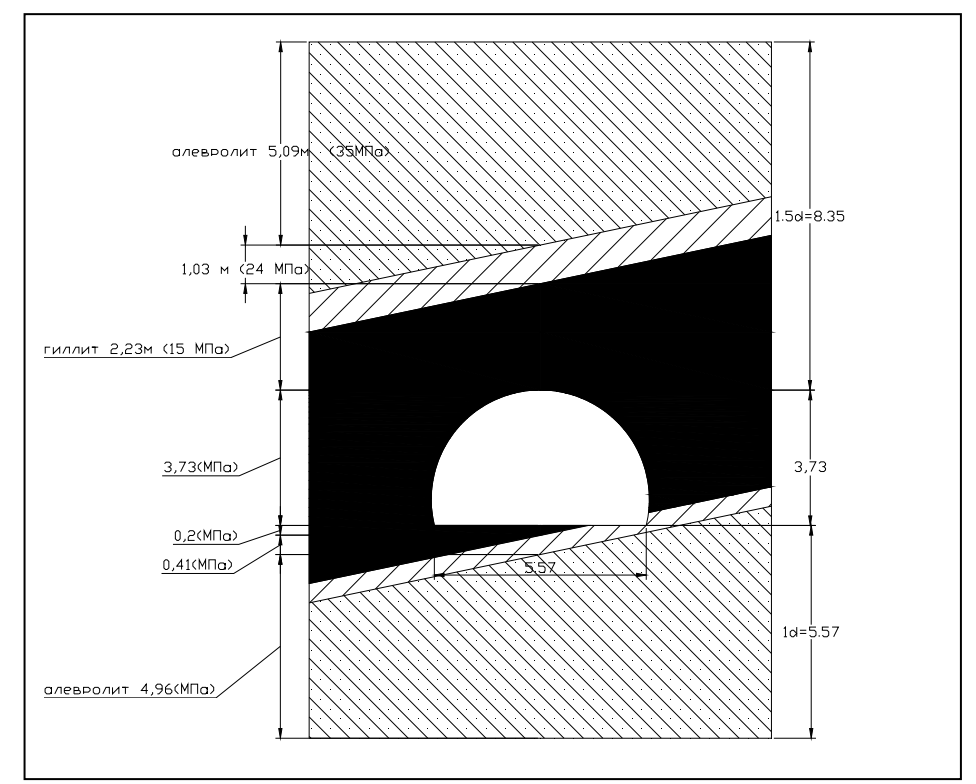

Рис. 1. Структура разреза вмещающих пород по конвейерному штреку $21 \kappa_{12}-\mathrm{c}$ шахты «Абайская» УД АО «АрселорМиттал Темиртау» 
a)

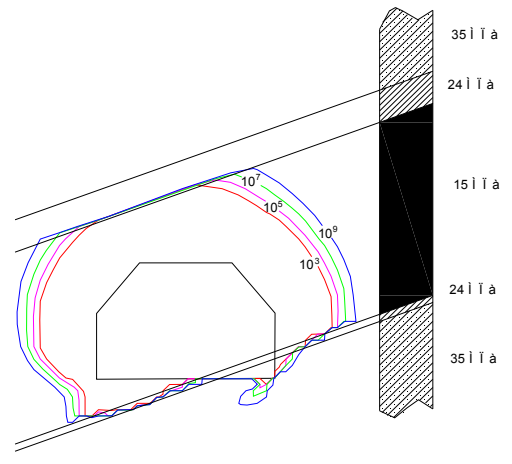

в) б)

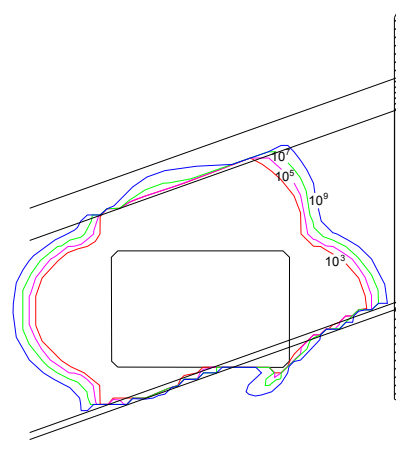

г)
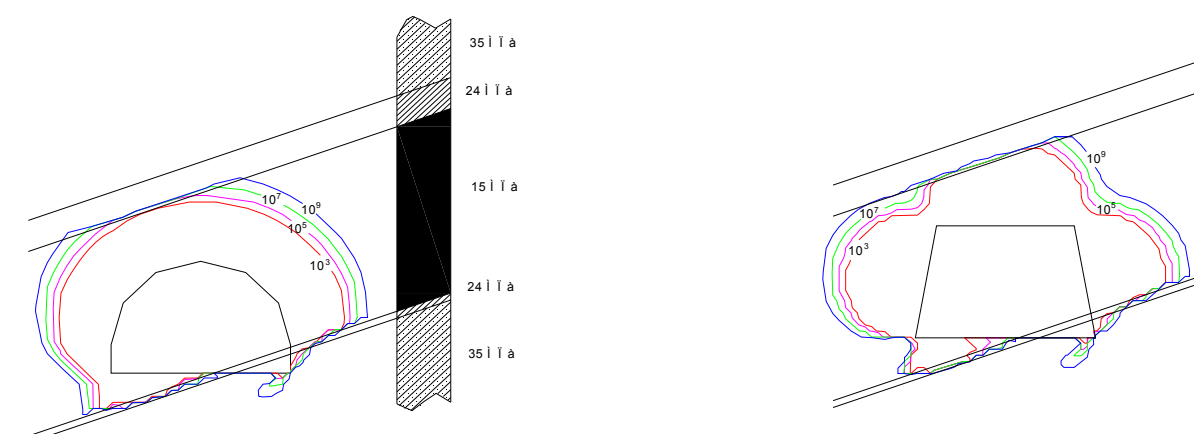

Рис. 2. Изолинии максимальных касательных напряжений, возникающих во вмещающих породах при различных формах поперечного сечения выемочных выработок: а - полигональная, б - прямоугольная, в - арочная и г - трапецевидная

a)

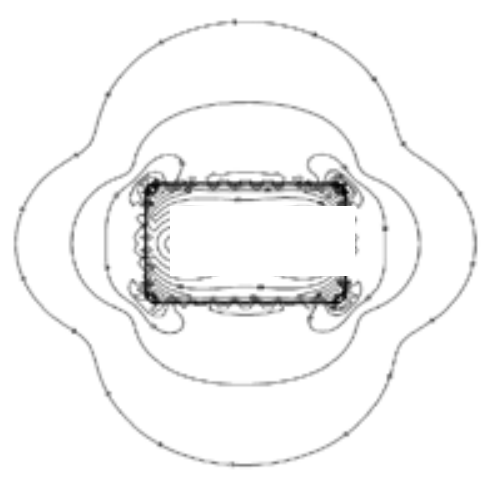

б)

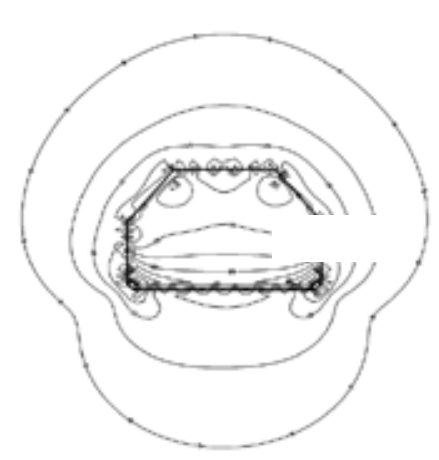

Рис. 3. Условные зоны неупругих деформаций вблизи выработки в различные периоды времени с момента обнажения пород при различной форме поперечного сечения: а - прямоугольная; б - полигональная 
массива на 0,5 ширины (высоты) сечения на свету, что приводит к пучению пород в полость выработки. После 0,3 ч условные зоны неупругих деформаций в кровле, боках и почве со стороны падения пласта составляли 2,0 м, 30 сут - 2,2 м, 4 месяца - 2,6 м. Коэффициент, учитывающий увеличение объема пород (диталансия) при их разрушении, принят в расчетах равным 1,1 .

Изменение угла наклона в диапазоне от 0 до $30^{\circ}$ не приводит к существенному изменению нагрузочной картины (для примера принята арочная форма крепи выемочной выработки). Зона растрескивания вмещающих горных пород, максимальная для горизонтально залегающих пластов, возникает на расстоянии 1,7-1,8 м и приближается к сечению выработки на 0,05 м при росте угла падения пласта на $10^{\circ}$ (рис. 4 ).

Оценка степени влияния управляемости пород кровли на деформируемость горного массива показала, что при легко- и среднеуправляемых породах в кровле, почве и пространстве боковых стенок плоскости трещины образуются на расстоянии 2,5-2,9 м от контура выработки, а при трудноуправляемых породах - в кровле непосредственно над выработкой.

В зависимости от управляемости вмещающих горных пород степень развития интенсивности трещинообразования рассмотрена при трапециевидной форме сечения выработки. Наиболее удаленно распространяется трещинообразование, причем со всех сторон выработки на расстоянии от контура $2,4-2,5$ м, и ещё менее удаленно $(0,4-0,5$ м) у боковых стоек в почве вблизи выработки - при легко- и среднеуправляемой кровле.

При трудноуправляемой кровле трещины в кровле приближены к выработке и находятся на расстоянии от сечения выработки, не превышающем 0,5 м.

Таким образом, характеристики управляемости вмещающих пород проявляются в большей степени по приближенности вновь образованных трещин к контуру выработки лишь при трудноуправляемой кровле (рис. 5).

Трещинообразование в кровле и боках от глубины расположения (на примере арочной формы) выработки 600 и 700 м отличается незначительно, начинается через 0,4 ч на глубине $1,2-1,5$ м в приконтурные породы и при периоде исследования, равном $1,5,15$ и 150 сут, распространяется с шагом 0,2 м вглубь массива. В почве тенденция распространения трещин подобна

a)

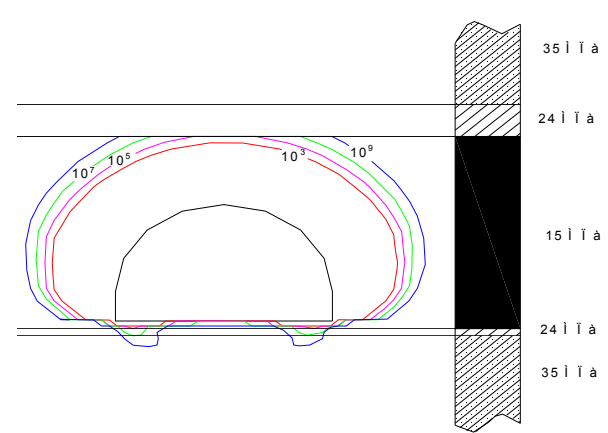

б)

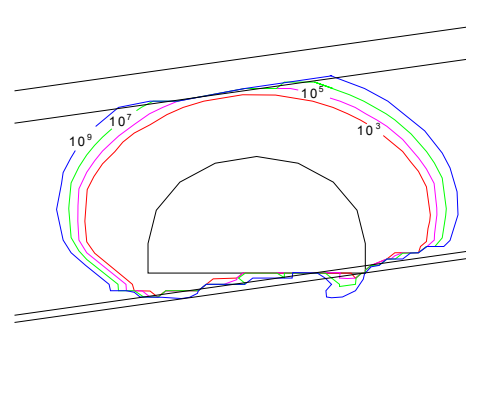

Рис. 4. Влияние угла падения угольного пласта на распределения максимальных касательных напряжений вокруг подготовительной выработки а) $-0^{\circ}$; б) - $10^{\circ}$ 

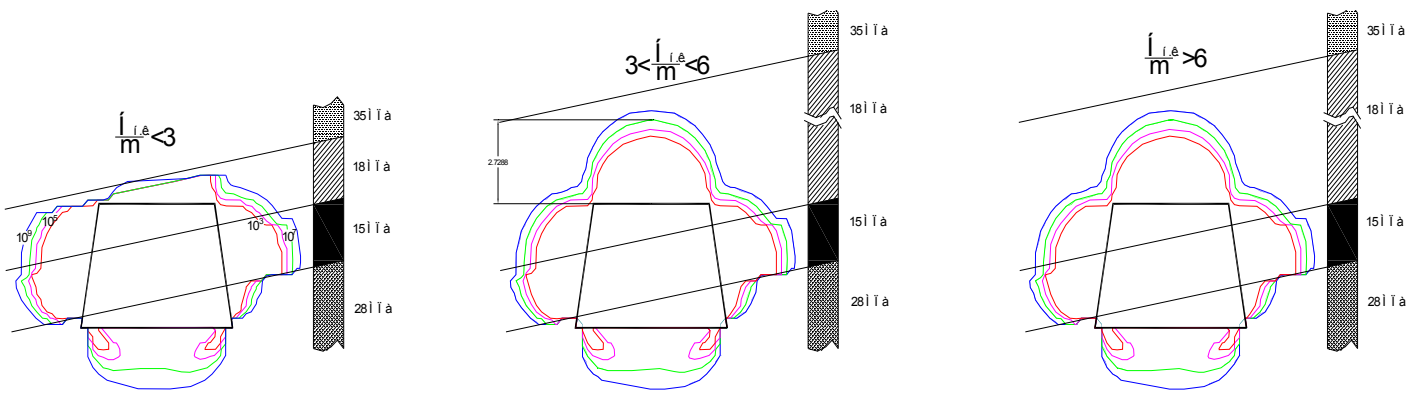

Рис. 5. Влияние управляемости пород кровли на деформируемость горного массива
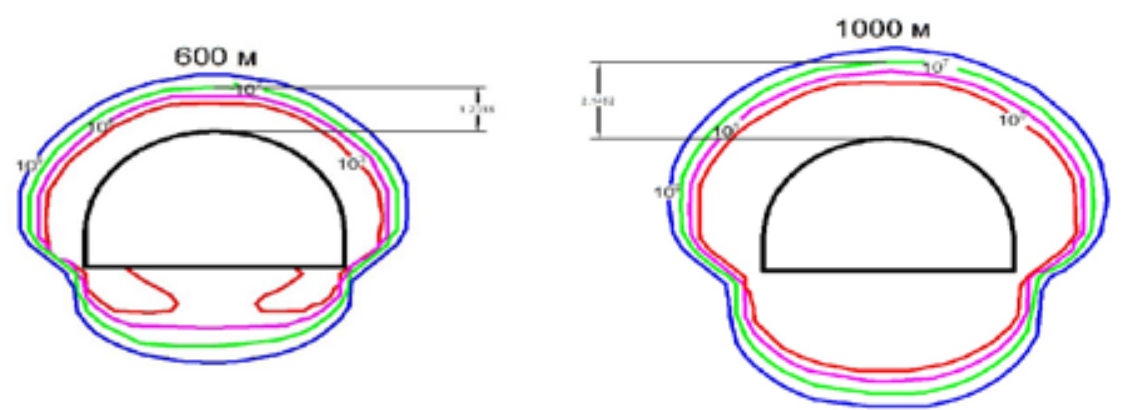

Рис. 6. Динамика распространения трещин в приконтурных породах выработки с ростом глубины ведения горных работ

трещинообразованию в кровле при тех же параметрах, но на первоначальном расстоянии от контура выработки 1,5 м.

На глубине 800 и 1000 м в кровле процесс начала трещинообразования смещается вглубь массива по сравнению с глубиной 600-700 м на 0,5-0,6 м (т.е. до 1,7-2,1 м), а в почве на 1,5-2,0 м и начинается на расстоянии 2,5-3,5 м. В целом, трещинообразование в кровле и боках выработки зависит от глубины в прямо пропорциональной зависимости, а в почве распространяется по гиперболитической связи. С ростом глубины разработки (с 600 до 1000 м) трещинообразование возрастает в 1,5 раза.

Первые эпюры условных зон неупругих деформаций от контура выработки располагаются на расстоянии 1,6-2,0 м.

На рис. 6 представлена динамика интенсивности развития зон трещинообразования во времени в зависимости от глубины расположения выработки в ее кровле, боках и почве.

На рис. 7 показана зависимость развития трещинообразования во времени $\left(N_{m}\right)$ в зависимости от глубины расположения $(H)$ при анкерной и металлоарочной крепи в кровле, боках и почве горной выработки.

Выявленные эмпирические зависимости:

- для кровли и боков $N_{m}=1,028+0,0004 H+0,056 T$,

- для почвы $N_{m}=1,387+0,0004 H+0,109 T$, м при $\mathrm{R}^{2}=0,94$.

$$
-80-
$$




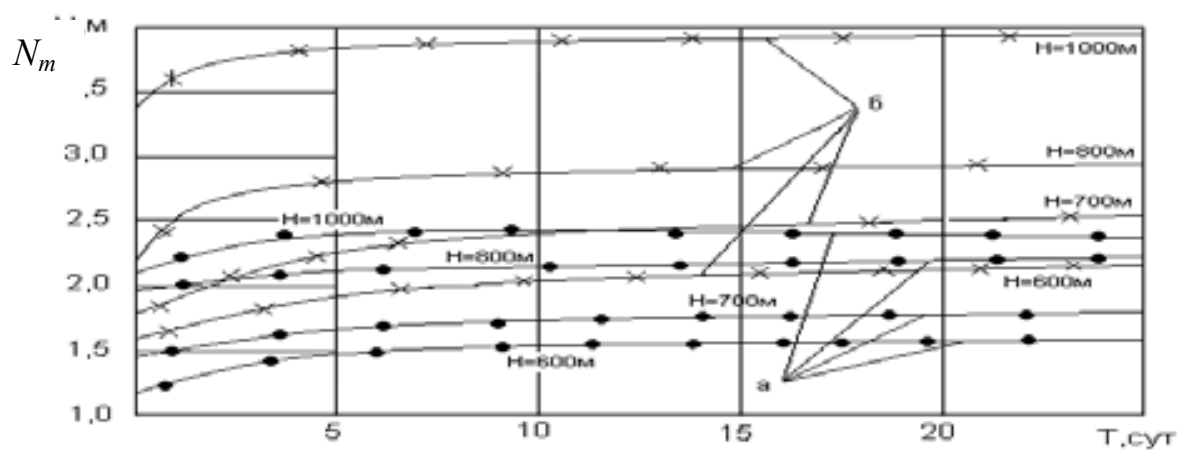

Рис. 7. Развитие трещинообразования во времени $\left(N_{m}\right)$ в зависимости от глубины расположения $(H)$ с комбинированным (анкерным и металлоарочным) креплением: а - в кровле и боках; б - в почве

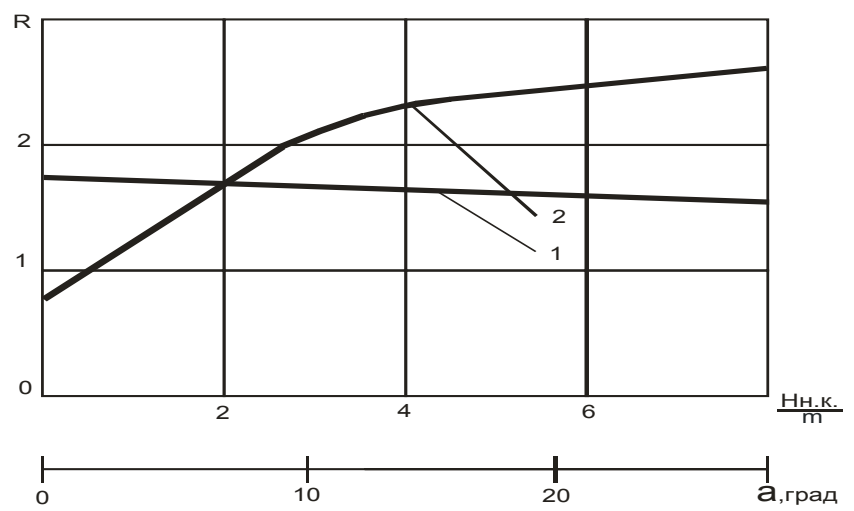

Рис. 8. Зависимость глубины распространения трещин $(R, \mathrm{M})$ во вмещающих породах в зависимости от угла падения пласта ( $\alpha$, град) и управляемости пород кровли: 1 - угол падения пласта; 2 - управляемость пород кровли

На рис. 8 представлена зависимость глубины распространения трещин во вмещающих породах в зависимости от угла падения пласта и управляемости пород кровли.

Проведенные исследования позволяют сделать вывод, что в рассматриваемых условиях разработки наиболее предпочтительной является арочная форма сечения выемочной выработки [1].

По степени влияния угла падения пласта на картину распределения максимальных касательных напряжений и долговечности по условным зонам неупругих деформаций установлено его несущественное влияние в диапазоне от 0 до $30^{\circ}$.

Установленные эмпирические зависимости:

$$
R=1,03+0,063 \frac{H_{\text {н.к. }}}{m}, R=1,8+0,05 \alpha, \text { м } \quad \text { при } \mathrm{R}^{2}=0,96 .
$$

Выполненные исследования позволили определить влияние горно-геологических и горнотехнических факторов на образование зон неупругих деформаций во вмещающих породах и 
установить рациональные параметры применения анкерной крепи в подготовительных горных выработках.

Исследование устойчивости контуров подготовительных выработок с учетом их напряженно-деформированного состояния в зависимости от горно-геологических факторов. Важной задачей является определение НДС массива с учетом влияющих факторов на устойчивость контуров горной выработки. В качестве расчетной схемы выбрана прямоугольная плоскость, находящаяся в плоскодеформированном состоянии и разбивающаяся сеткой треугольных элементов (размером 0,2-0,3 м) с граничными условиями с решением задачи методом конечных элементов (МКЭ).

На расчетной схеме приняты следующие допущения: на контуры выработки действует нагрузка от веса вышележащих пород; за пределами боковых границ отсутствуют горизонтальные, а за нижней - вертикальные смещения массива.

С ростом глубины разработки увеличивается НДС в горном массиве. На примере металлоарочной крепи установлено, что с ростом глубины от 600 до 1000 м резко растут (в прямо пропорциональной зависимости) и имеют наибольшее значение касательные напряжения (от 120 до 200 Па) с незначительным увеличением продольных (от 20 до 40 Па) и нормальных (от 10 до13 Па) напряжений.

С увеличением угла падения угольного пласта от 6 до $12^{\circ}$ при металлоарочном креплении выработки изменяются лишь нормальные напряжения, а продольные напряжения, вертикальные и продольные смещения остаются незменными (рис. 9,a). При анкерном креплении с изменением угла падения пласта перемещения в рассматриваемом диапазоне не меняются, а напряжения растут с пиком колебания ( $\sigma_{x}-$ максимум, $\sigma_{y}-$ минимум) при $10^{\circ}$ (рис. 9,б). Коэффициент бокового распора принят равным $0,25-0.3$.

Зоны развития растягивающих напряжений наблюдаются у почвы выработок. Для вертикальных напряжений эта зона охватывает всю вышерасположенную относительно почвы область горных пород (рис. 10).

Проведенные исследования позволили установить степень влияния горно-геологических условий разработки на эффективность применения металлоарочного и анкерного крепления выемочных выработок.

a)

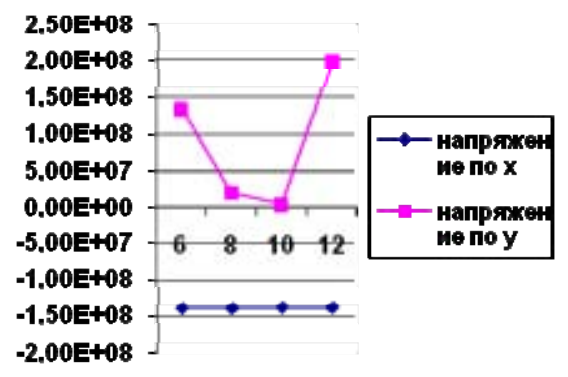

б)

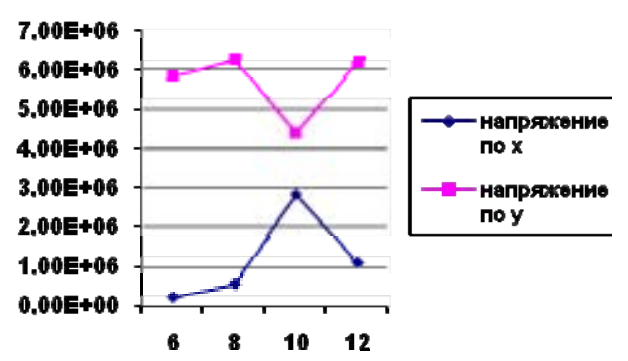

Рис. 9. Характер распространения напряжений и смещений в зависимости от изменения угла падения пласта: а - металлоарочное; 6 - анкерное крепление 

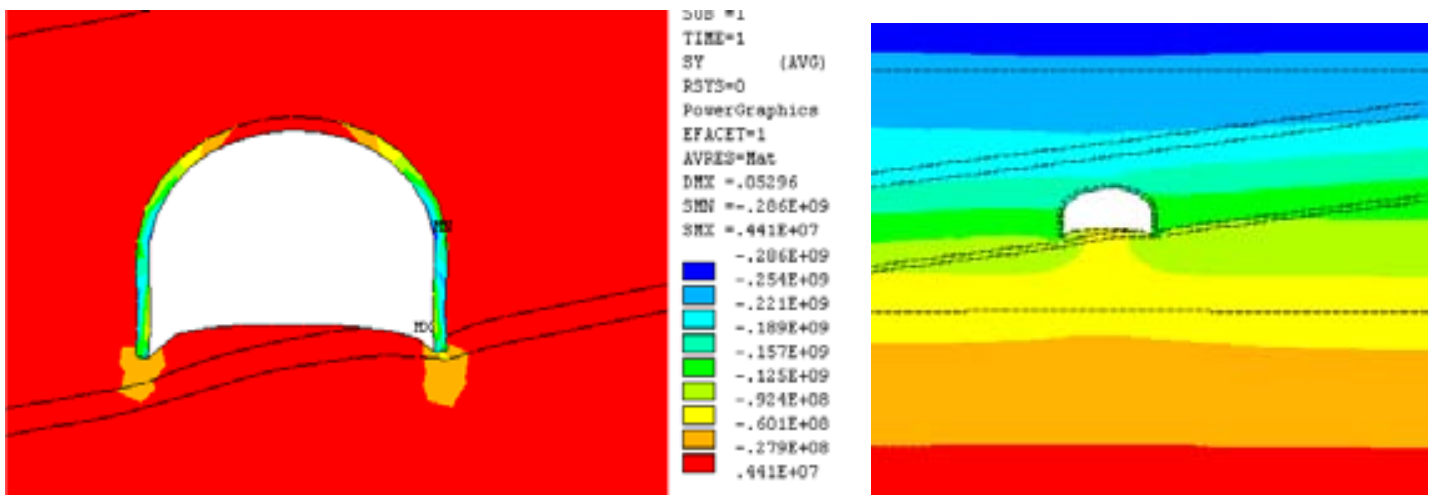

Рис. 10. Характер распространения напряжений и смещений при металлоарочном креплении
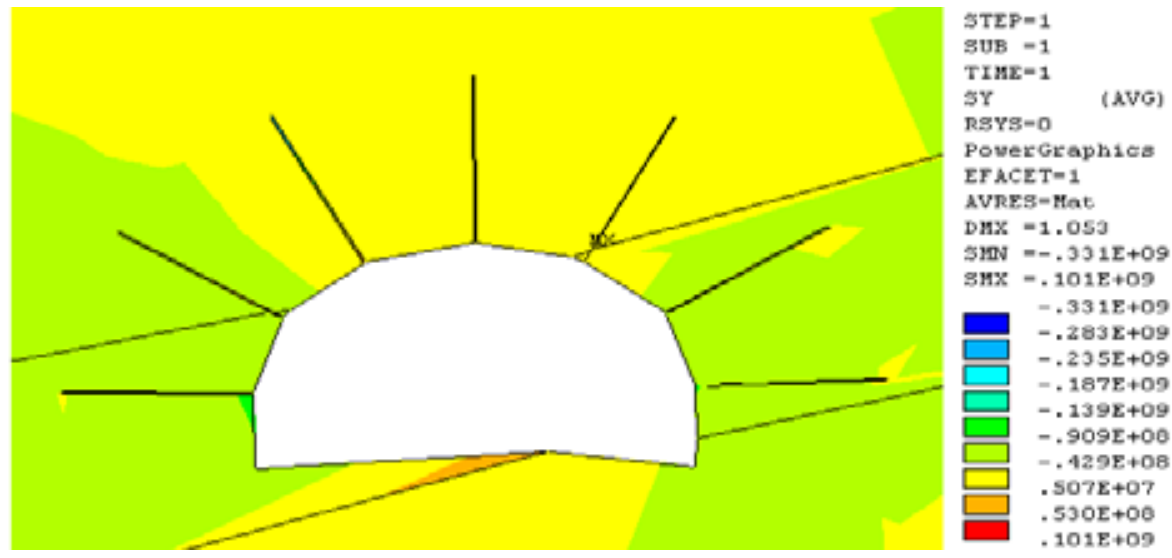

Рис. 11. Проявления горного давления в конвейерной выработке $\left(\sigma_{y}\right)$ при технологии очистных работ с возвратно-точной схемой проветривания

Исследование напряженно-деформированного состояния выемочных выработок в зависимости от влияния технологических факторов с использованием метода конечных элементов

Моделировалась технологическая схема очистных работ с возвратно-точным проветриванием для условий пласта к 10 шахты «Абайская» УД АО «АрселорМиттал Темиртау» при длине лавы 200 м вне зоны влияния очистных работ с использованием анкерной крепи.

По деформациям рассчитывают напряжения нормальные $\sigma_{x}$, продольные $\sigma_{y}$ и касательные $\tau_{x y}$. На рис. 11 представлена картина вертикальных напряжений $\left(\sigma_{y}\right)$ вокруг конвейерной выработки с зоной растяжения $\sigma_{y}=5,0$ МПа.

На рис. 12 показана вентиляционная выработка, закрепленная анкерами. Со стороны выработанного пространства вышележащего столба выработка задавлена растягиваюшими напряжениями со стороны пород кровли ( $\left.\sigma_{y}=5,0 \mathrm{MПа)} \mathrm{и} \mathrm{поддута} \mathrm{с} \mathrm{почвы} \mathrm{(} \sigma_{y}=5,3 \mathrm{MПа}\right)$, со стороны лавы сохраняет относительную устойчивость, при сжимающих напряжениях $\sigma_{y}=43-90$ МПа. Вертикальные смещения $\left(\Psi_{y}\right)$ в кровле выработки составляют 1,0 м, в боках $-0,7-0,8$ м, в почве $-0,6$ м. Горизонтальные смещения $\left(U_{x}\right)$ со всех сторон 0,35 м. Таким образом, анкерное 


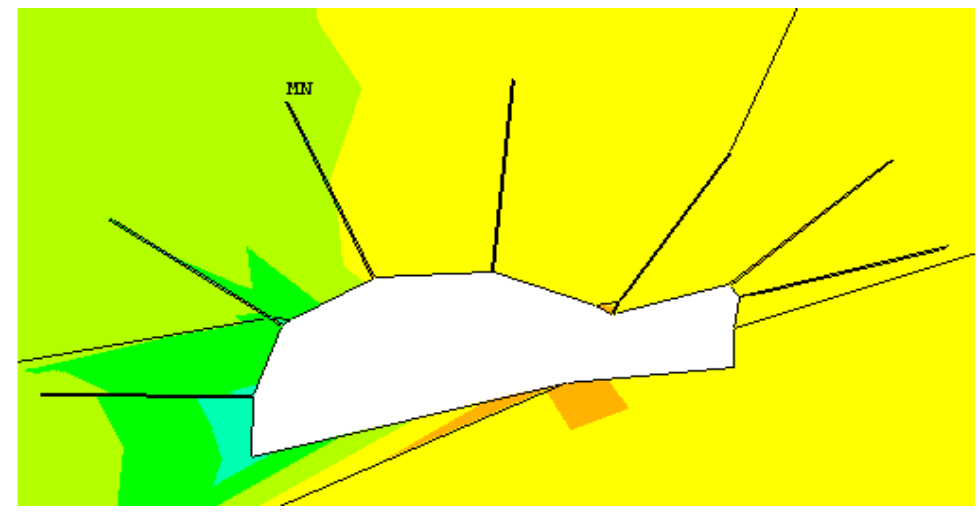

Рис. 12. Проявления горного давления $\left(\sigma_{y}\right)$ вокруг вентиляционной выработки

крепление даже до подхода лавы не выдерживает действующего давления и требует установки усиления крепления.

Конвейерная выработка (рис. 11), закрепленная анкерной крепью, до подхода лавы сохраняет устойчивость при растягивающих напряжениях $\sigma_{y}=5$ МПа в кровле (почве) и напряжениях сжатия $\sigma_{y}=50$ МПа в боках выработки.

Проведенные исследования по установлению влияния управляемости пород кровли пласта (соотношения мощности пород непосредственной кровли к вынимаемой мощности пласта) при металлоарочной и анкерной крепи показали, что с ростом мощности пород непосредственной кровли все напряжения имеют неинтенсивную динамику роста.

При любом из рассматриваемых видов крепи горной выработки с ростом управляемости вмещающих пород напряжения в массиве растут по линейной зависимости. Причем вертикальные напряжения $\left(\delta_{y}\right)$ растут незначительно при арочной и анкерной крепях и близки по величине.

Продольные напряжения $\left(\delta_{x}\right)$ при арочной крепи по сравнению с анкерной меньше в два раза, а касательные - больше в четыре раза. Для металлоарочной крепи большие значения характерны для касательных напряжений ( $t_{x, y}=120-140$ Па), а для анкерной - продольных напряжений $\left(\sigma_{x}=60-70\right.$ Па) с примерно одинаковой величиной их соответствующих сопутствующих напряжений в диапазоне 30-40 Па и минимальны нормальные напряжения - 3-10 Па (рис. 13,a и 13,б).

Моделировалось НДС приконтурного массива горных пород вокруг выработки с изменением длины и диаметра анкерной крепи. Касательные напряжения с ростом длины анкера (в диапазоне 1,8-2,4 м) не меняются, а вертикальные и продольные - растут по неярко выраженной зависимости.

С изменением диаметра анкера в диапазоне (0,02-0,024 м) вертикальные и продольные напряжения растут, а касательные напряжения уменьшаются по линейной зависимости.

В обоих случаях с ростом длины анкера (с 1,8 до 2,2 м) и его диаметра $(0,02-0,024$ м) более значительны продольные напряжения (55-60 Па) с тенденцией их повышения. Касательные напряжения практически неизменны (25 Па) в рассматриваемом диапазоне, а нормальные напряжения незначительно растут по линейной зависимости (от 5 до 10 Па). 
a)

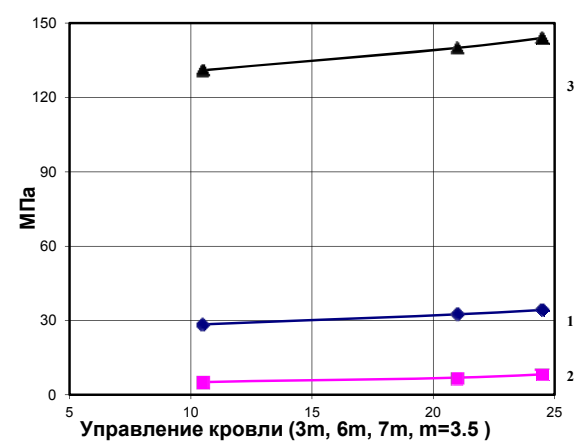

в)

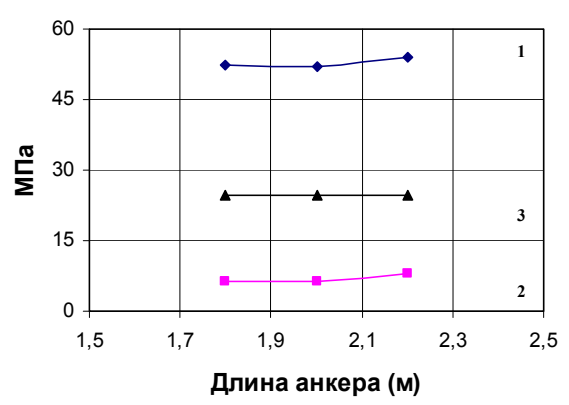

б)

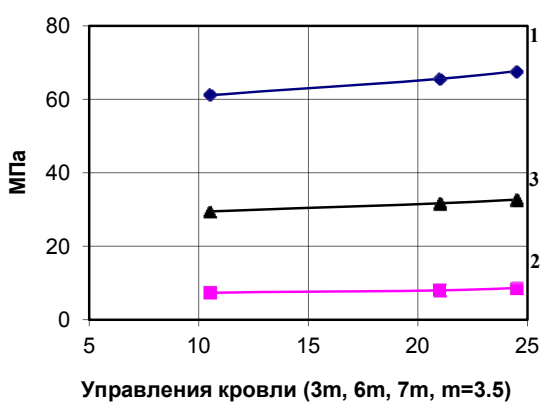

г)

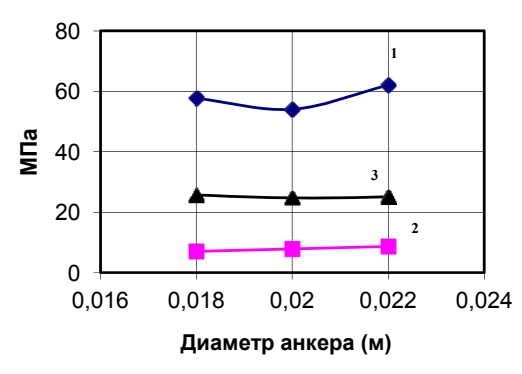

Рис. 13. Влияние управляемости пород кровли на величину напряжений, возникающих вокруг контура крепи выработки: а - металлоарочная; б - анкерная крепь; в - с изменением ее длины; г-диаметра анкера (м); 1 - напряжение по $x ; 2$ - напряжение по $y ; 3$ - касательное напряжение

Выявленные закономерности изменения напряженно-деформированного состояния угля породных массивов (смещений, напряжений, зон трещинообразования) в зависимости от основных горно-геологических и горно-технических факторов позволят в конкретных условиях эксплуатации устанавливать параметры крепления для повышения устойчивости подготовительных горных выработок.

Определение гранищы области неупругих деформащий методом последовательных нагружений. Такая задача теории упругости о напряженном состоянии вокруг горной выработки решается многократно, причем каждый раз с новым внутренним контуром посредством метода граничных интегральных уравнений.

Напряженное состояние пород представляется как основное (напряжения в нетронутом массиве) и дополнительное (создаваемое нагрузками, приложенными по периметру, соответствующему контуру выработки в плоскости без выработки). При этом нагрузки должны быть такими, чтобы вызванные ими напряжения, сложенные со значениями напряжений основного напряженного состояния, давали на контуре выработки заданные граничные условия, т.е. они компенсировали бы напряжения нетронутого массива.

Процесс определения зоны неупругих деформаций осуществляется поэтапно: первоначально устанавливается минимальная величина нагрузки на массив, при которой появляется зона неупругих деформаций вокруг выработки, а затем последующее нагружение разбивается на ряд этапов, для каждого из которых строится контур зоны, в пределах которой породы на- 
a)

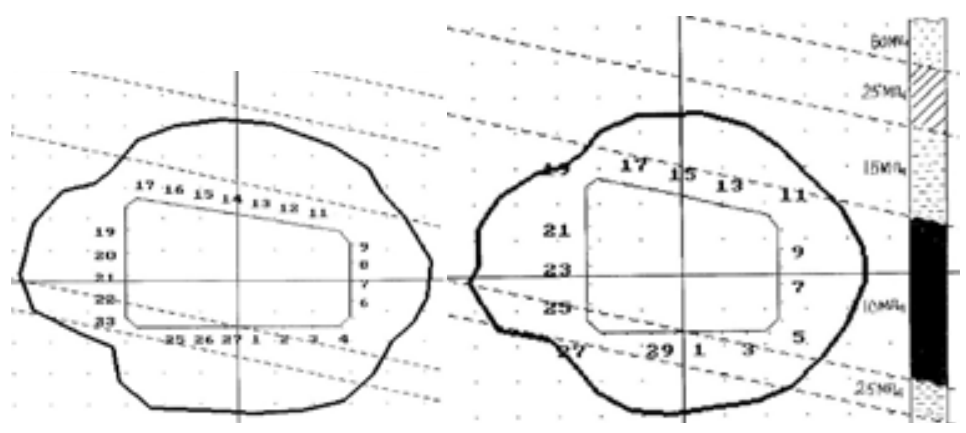

$60 \mathrm{MПа}$

б)
Рис. 14. Границы области неупругих деформаций вокруг контура конвейерного штрека $45 \kappa_{10}-3$ шахты «Абайская» при расчетах методом последовательных нагружений: а и б - соответственно прямоугольное и квадратное сечение выработки

ходятся в неупругом состоянии. Контур зон неупругих деформаций определяется по направлениям - лучам, где происходит разрушение пород путем сдвига или отрыва. Расчет производится последовательно от каждого промежуточного достигнутого состояния. Выполняемые методом последовательных нагружений расчеты (рис. 14) позволили установить границы области неупругих деформаций вокруг контура конвейерного штрека $45 \kappa_{10}-3$ сечением в свету 16,2 м²при глубине горных работ 630-640 м шахты «Абайская», которые с разницей 7-10\% идентичны условным зонам долговечности массива пород, полученным по методу граничных интегральных уравнений (условных зон неупругих деформаций).

Деформирование боковых пород горной выработки от угла падения пласта и глубины анкерования. Аналитическое моделирование выполнено с применением численного МКЭ для условий конвейерной выработки пласта $\kappa_{10}$ шахты «Абайская» УД АО «Арселор Миттал Темиртау» при глубине разработки 400 м и мощности пласта 3,8 м, для которого в программном комплексе ANSYS была построена модель массива вмещающих горных пород.

Было исследовано влияние формы сечения горной выработки и угла падения угольного пласта на величину возникающих максимальных напряжений в массиве горных пород при креплении выработки анкерной крепью.

При сводчатой (арочной) форме поперечного сечения выемочной выработки нормальные напряжения $\left(\sigma_{y}\right)$ растут при увеличении угла падения пласта $(\alpha)$ с $10^{\circ}$ до $40^{\circ}$ по показательной функции в диапазоне от 10 до 13,5 МПа (рис. 15,a). Продольные напряжения $\left(\sigma_{x}\right)$ увеличиваются при $\alpha$ от $10^{\circ}$ до $20^{\circ}$ в диапазоне от 63,2 до 64,1 МПа, а затем влияние угла падения не проявляется (рис. 15,б). Минимальные напряжения присущи прямоугольной форме сечения выработки. Причем большие напряжения возникают по восстанию угольного пласта (рис. 16, а и б).

Проведенные исследования позволяют сделать вывод о предпочтительности применения для условий разработки пласта $\kappa_{10}$ шахты «Абайская» УД АО «АрселорМиттал Темиртау» прямоугольной формы сечения выемочных выработок с анкерным креплением вмещающих пород. 
a)

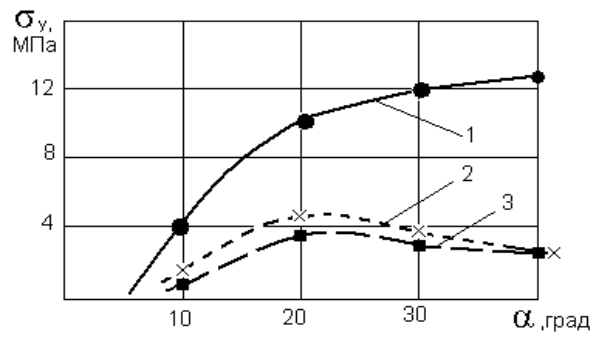

б)

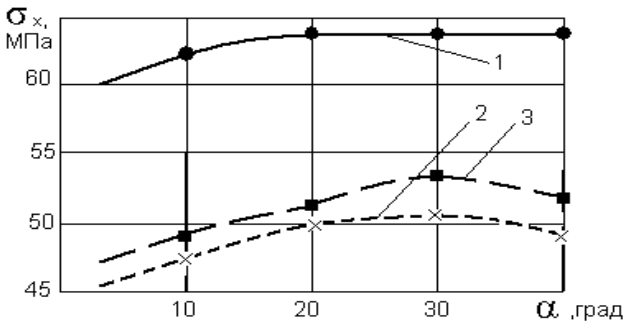

Рис. 15. Влияние вида формы выработки и угла падения пласта на величину максимальных напряжений в массиве пород при анкерном креплении выработки: а - максимальные нормальные; б - продольные; 1 - арочная; 2 - полигональная; 3 - прямоугольная

a)

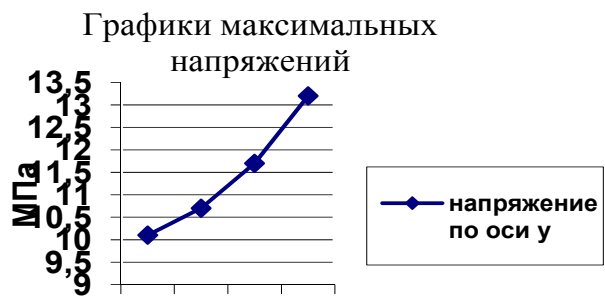

10203040 Градусы б)

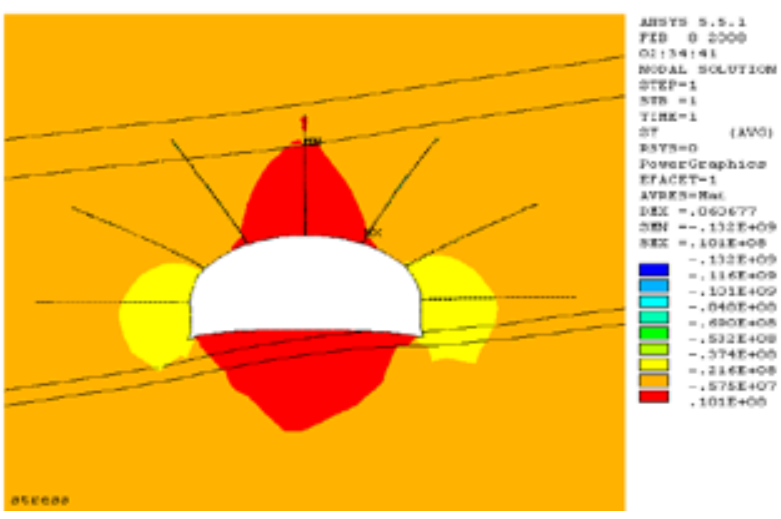

Рис. 16. Распределение максимальных напряжений в боковых породах, окружающих выработку с формой

Исследован характер изменения и распределения напряжений в кровле, почве и боках выработки. При величине слоя легкообрушающихся пород от 1,03 до 6,0 м и длине анкера от 2,4 до 5,0 м происходят следующие изменения напряжений вокруг выработки.

Максимальные и минимальные нормальные напряжения с ростом длины анкера (с 1,5 до 6 м) и увеличением мощности слоя легкообрушающихся пород (например, сложенного аргиллитом) с 1 до 6 м растут в пропорциональной линейной зависимости (рис. 17,a). Изменения напряжений в рассматриваемом диапазоне в продольной плоскости с ростом длины анкера и увеличением толщины слоя легкообрушающихся пород имеют следующие тенденции: растягивающие - уменьшаются, а сжимающие - имеют скачок при длине анкера 3,0-3,5 м и в целом находятся в узком диапазоне (42-48 МПа) (рис. 17,б), т.е. более эффективны анкеры длиной $3,5-4,0 \mathrm{M}$.

Закономерности изменения касательных напряжений имеют тенденцию роста при толщине слоя аргиллита 5 м, а при толщине слоя аргиллита 1,0-3,5 м увеличиваются при изменении длины анкера с 1,5 до 3,0 (3,5) м, а затем снижаются. При этом увеличение диаметра шпуров 
a)

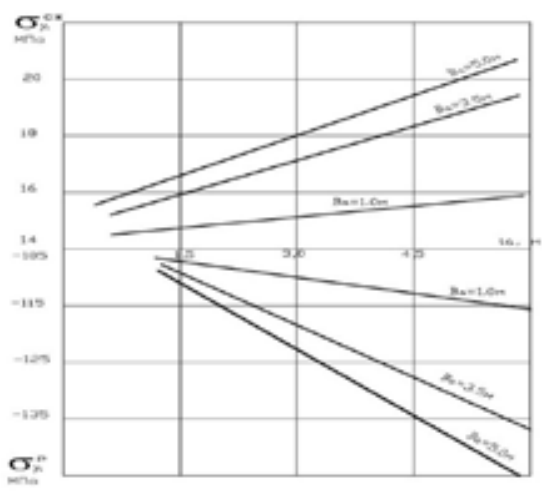

б)

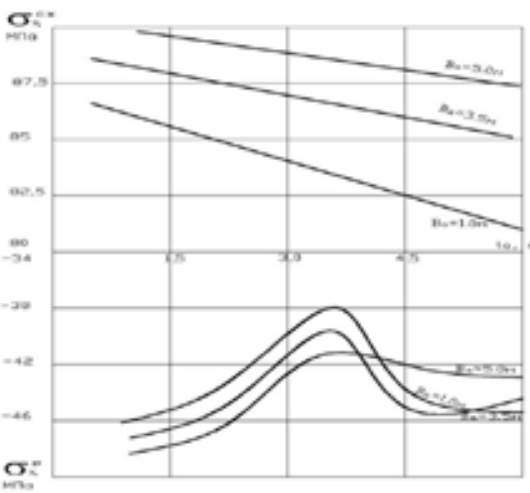

Рис. 17. Изменение напряжений в приконтурных породах подготовительной выработки от длины анкерирования и мощности слоев: а) - нормальные; б) - продольные

a)

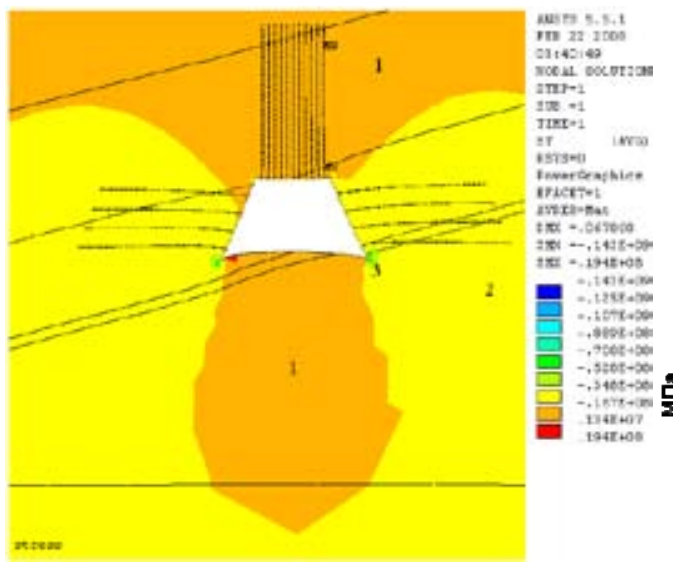

б)

Изменения напряжений в зонах вокруг выработми

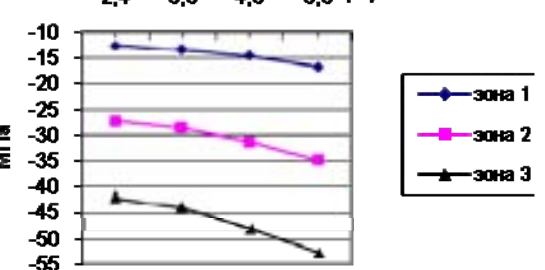

Рис. 18. Эпюра распределения и зависимость и нормальных напряжений во вмещающих породах от глубины их анкерирования: слой аргиллита $-5,0$ м, длина анкера $-l=3,5$ м; а - эпюра; б - зависимость

(до 0,05 м) негативно сказывается на возникающих напряжениях и приводит к их двукратному росту на всем диапазоне.

Проведенные исследования НДС вмещающих пород в зависимости от мощности слоя легкообрушающихся пород при разной длине анкерирования позволили установить следующий характер поведения боковых пород по зонам их расположения (рис. 18 a, б).

На рис. 19 представлено распределение нормальных и продольных напряжений при слое аргиллита 7,5 м по контуру горной выработки. Анализ распределения напряжений показывает, что вокруг выработки возникают зоны неустойчивых горных пород.

В большей степени это касается кровли и почвы выработки, а также ее боков в области нижней части боковых сторон контура выработки. Максимальное значение нормальных напряжений возникает в расположенном на кровле выработки правом крайнем анкере в месте его 
a)

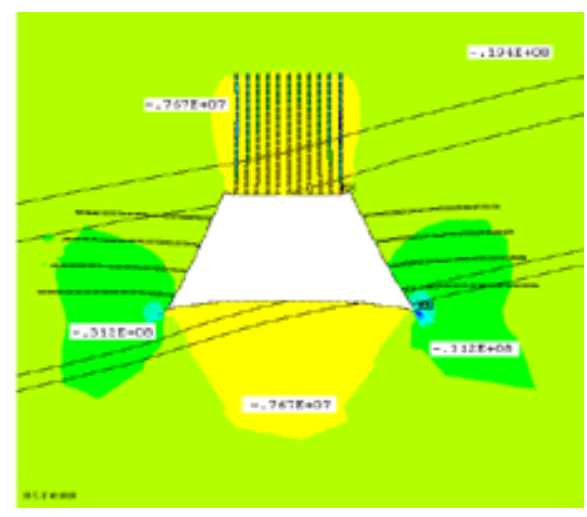

б)

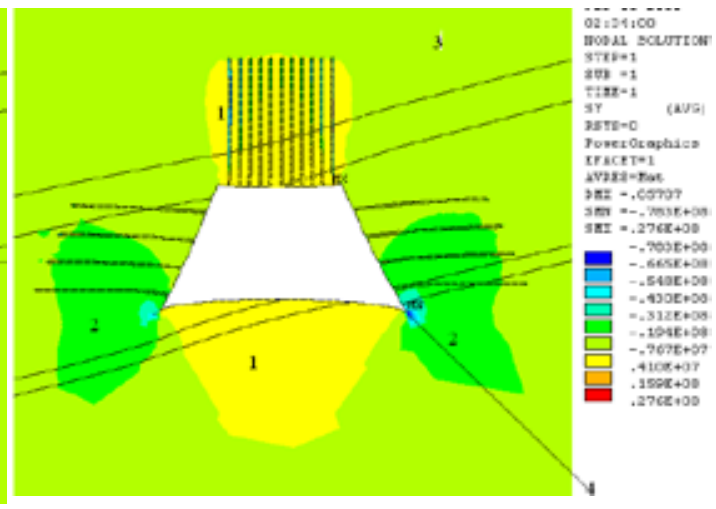

Рис. 19. Распределения нормальных (а) и продольных (б) напряжений при слое аргиллита 7,5 м: 1 - зона весьма неустойчивая; 2 - неустойчивая; 3 - средней устойчивости; 4 - устойчивая

закрепления. Максимальное значение продольного напряжения возникает в анкере, расположенном на правой боковой поверхности выработки (первый снизу).

Произведенные расчеты показали удовлетворительную сходимость с экспериментальными замерами деформаций пород рассматриваемых эксплуатируемых выработок.

Оиенка напряженно-деформированного состояния массива пород аналитическим и экспериментальным методами. Моделирование выполнено для конвейерного штрека $31 \kappa_{12}$-ю шахты «Абайская» УД АО «АрселорМиттал Темиртау» при глубине разработки 390 м, геологической мощности пласта $\kappa_{12}$, равной 6 м, для технологической схемы ее проведения, представленной на рис. 20.

На рис. 21 ихзображена расчетная схема и модель выработки прямоугольного сечения площадью 15 м² (ширина 5 м и высота 3 м).

Исследованиями установлены следующие значения вертикальных перемещений: $U_{\kappa p}=108$ мм, $U_{n \psi}=67$ мм, $U_{6 .}=89$ мм, соответствующих исследуемым точкам 4, 6, 5 на рис. 21.

Распределение значений вертикальных напряжений $\left(\sigma_{y}\right)$ в массиве приконтурных пород в исследуемых точках 1, 2, 3 (см. рис. 21) характеризуется зависимостью (1) рис. 22.

Значения вертикальных напряжений в области боковых стоек выработки симметричны и имеют значения в кровле $\sigma_{y}=-60,22$ МПа, в боках $\sigma_{y}=-29,26$ МПа и в почве $\sigma_{y}=-68,83$ МПа.

Эта же задача рассмотрена с учетом крепления анкерами (длина 2,4 м, диаметр 0,022 м) кровли выработки.

Расположение анкеров в кровле - вертикальное или близкое к нему. В результате произведенных расчетов получены следующие значения вертикальных перемещений: $U_{\kappa p}=108$ мм, $U_{n ч}=67$ мм, $U_{6 .}=89$ мм, соответствующих точкам 4, 6, 5 рис. 21. Изменение нормальных напряжений $\left(\sigma_{y}\right)$ в точках 1, 2, 3 иллюстрируются зависимостью (2) рис. 22.

Значения нормальных напряжений у боковых стоек выработки симметричны и имеют следующие значения: в кровле $\sigma_{y}=-6,22$ МПа, в боках $\sigma_{y}=-29,78$ МПа и в почве $\sigma_{y}=-69,57$ МПа. 

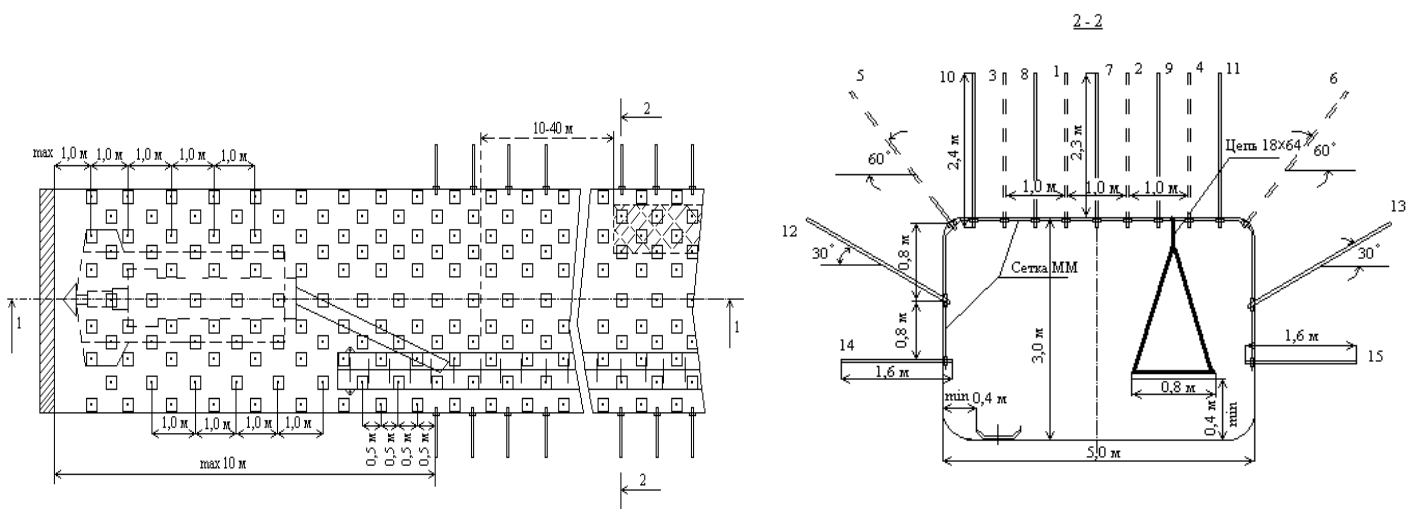

Рис. 20. Технологическая схема проведения конвейерного штрека $31 \kappa_{12}$-ю шахты «Абайская» УД АО «АрселорМиттал Темиртау»: а - продольный разрез; б - поперечное сечение
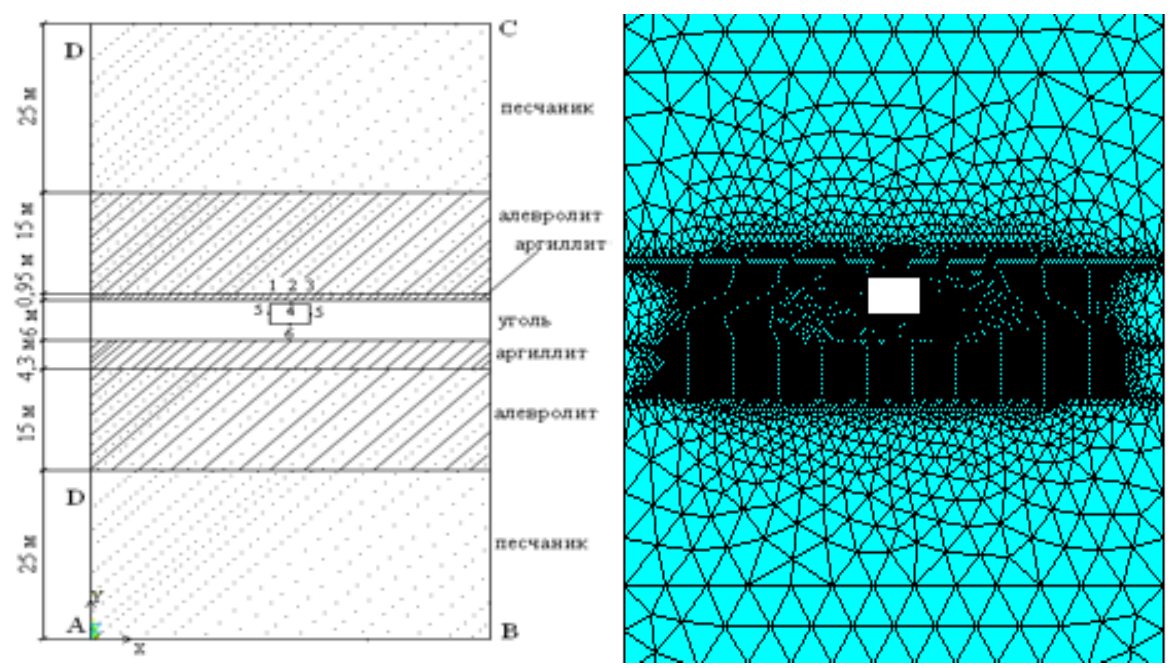

Рис. 21. Расчетная схема модели приконтурных пород вокруг горной выработки, разбитая на конечные элементы

Проведенные исследования показывают, что перемещения в обеих задачах - без- и с анкерным креплением - в кровле выработки в боках и почве остаются без изменения. Расчетные перемещения по паспорту проведения и крепления забоя конвейерного штрека $31 \kappa_{12}$-ю шахты «Абайская» УД АО «АрселорМиттал Темиртау» составляют $U_{k p}=106,6$ мм, $U_{n \psi .}=187$ мм, $U_{6 .}=84,08$ мм.

Сравнивая эти значения с данными, полученными численным методом, можно сделать следующее заключение:

- погрешность вычисления перемещений в кровле между численным и аналитическим методом составляет около $2 \%$;

- погрешность вычисления перемещений в боках между численным и аналитическим методом около $6 \%$; 


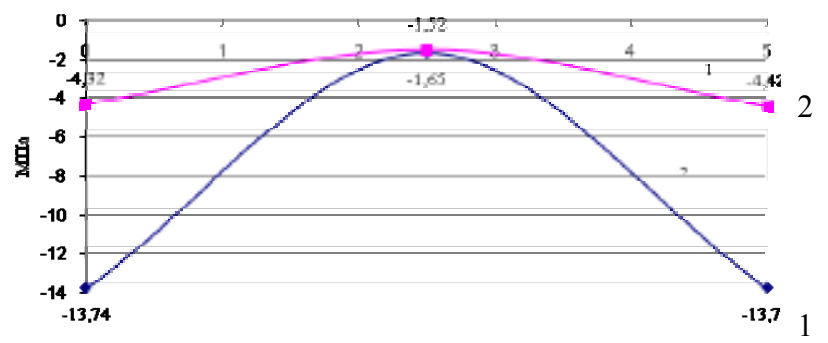

Рис. 22. Напряжения в массиве приконтурных пород без и при креплении анкерами кровли выработки: 1 - вертикальные; 2 - нормальные

- перемещения в почве, полученные аналитическим путем, в 2,8 раза больше перемещений, полученных численным методом.

Из зависимости (рис. 22) следует, что в условиях крепления кровли выработки анкерами напряжение $\sigma_{y}$ по модулю уменьшилось.

Рассматривая распределения нормальных напряжений $\sigma_{y}$ в случае, когда кровля не закреплена анкерами, проверим задачу на прочность каждого слоя (расположение слоев показано на рис. 21):

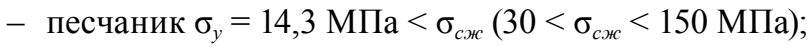

- алевролит в зоне кровли выработки $\sigma_{y}=14,3 \mathrm{MПа}<\sigma_{c \varkappa}\left(30<\sigma_{c \varkappa}<95 \mathrm{MПа);}\right.$

- аргиллит в зоне кровли выработки $\sigma_{y}=6,5 \mathrm{MПа}<\sigma_{c \varkappa}\left(12<\sigma_{c \varkappa}<70 \mathrm{MПа}\right)$;

- уголь в зоне кровли выработки $\sigma_{y}=6,5$ МПа $<\sigma_{c \varkappa}\left(13<\sigma_{c \varkappa}<30\right.$ МПа);

Проверяем на прочность те же слои для случая, когда кровля закреплена анкерами:

- песчаник $\sigma_{y}=29,7 \mathrm{MПа}<\sigma_{c \varkappa}\left(30<\sigma_{c \varkappa}<150 \mathrm{MПа}\right)$;

- алевролит $\sigma_{y}=29,7 \mathrm{MПа}<\sigma_{c \varkappa}\left(30<\sigma_{c \varkappa}<95\right.$ МПа);

- аргиллит в зоне кровли выработки $\sigma_{y}=3,68 \mathrm{MПа}<\sigma_{\text {сж }}\left(12<\sigma_{\text {сж }}<70 \mathrm{MПа}\right)$;

- уголь в зоне кровли выработки $\sigma_{y}=3,68$ МПа $<\sigma_{c \varkappa}\left(13<\sigma_{c \varkappa}<30\right.$ МПа).

Из вышеизложенного следует, что сжимающие напряжения уменьшаются и характер их изменения представлен на рисунке 22).

При этом в кровле и в почве породы весьма неустойчивы, в боках породы - наоборот, достаточно устойчивы. Анкеры в кровле работают на сжатие. В анкерах, направленных под углом к кровле, возникают максимальные растягивающие напряжения. Максимальное напряжение располагается в точке соединения стойки с кровлей и достигает значения 74,3 МПа. Максимальные сжимающие значения напряжений также возникают в анкере, установленном под углом к кровле, и составляют 160 МПа.

Исследование технологического расслоения пород. Исследован способ, обосновывающий применение ограниченно податливой анкерной крепи, которая влияет на развитие зон разрушения в приконтурных породах посредством связывания и упрочнения их в пределах первоначальных зон расслоения, образующихся вне зоны влияния очистных работ, для создания предохранительного моста, распределяющего давление на пяты свода и играющего в последующем в зоне опорного давления роль перераспределителя пригрузки от пришедших в сдвижение вышележащих пород. 
a)

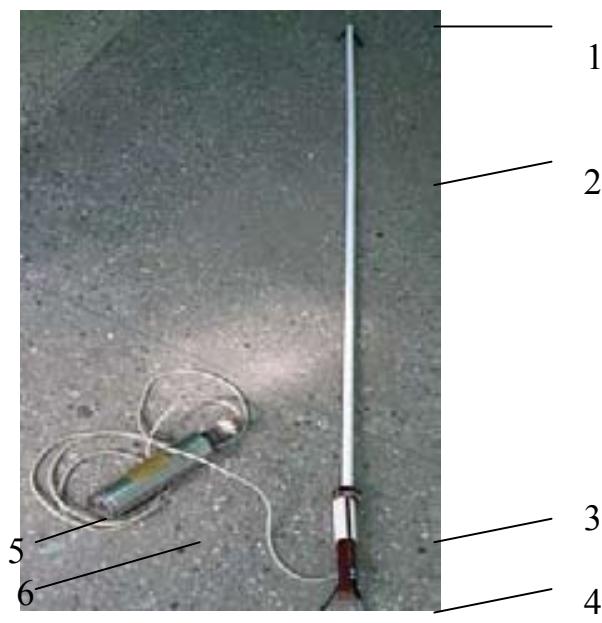

б)

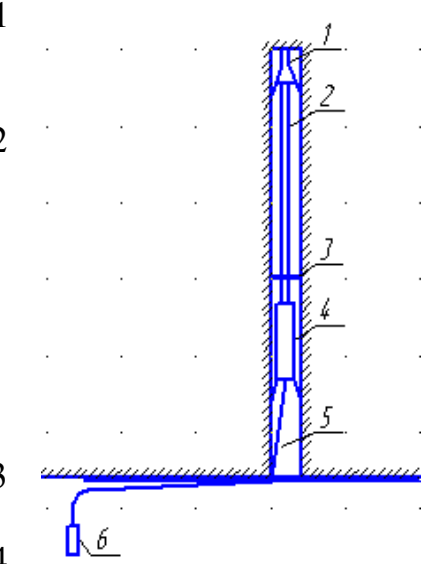

Рис. 23. Общий вид (а) и схема производства замеров (б) приборами контроля деформаций массива КДМ-1 и 2: 1, 2 - базовый репер и его шток; 3 - упорная шайба; 4 - датчик; 5 - соединительный кабель; 6 - прибор КДМ-2

Определение области первоначального расслоения пород позволяет прогнозировать устойчивость и обрушаемость пород кровли и боков выработок для выбора рациональных параметров их проведения. Для определения расслоения пород проведен дистанционный контроль оценки НДС горных массивов, разрушения кровли и смещений боков выработок посредством приборов контроля деформации КДМ-1 и КДМ-2 (конструкции ВНИМИ). С помощью первого прибора осуществлялся визуальный контроль за расслоениями в массиве, а прибором КДМ-2 количественно оценивалось смещение массива и расслоение в породах кровли (рис. 23). Смещения замерялись в приконтурных породах на конвейерном штреке $71 \kappa_{10}$-в шахты «Саранская» УД АО «АрселорМиттал Темиртау» на глубине 450 м. Для контроля были пробурены три шпура (центральный и два под углом $45^{\circ}$ к нему) в кровлю выработки. Непосредственная кровля пласта представлена среднеустойчивыми аргиллитами мощностью от 1 до 5 м прочностью 15-20 МПа с расстоянием между трещинами 0,5 м и основной труднообрушаемой кровлей мощностью 24-30 МПа, сложенной песчаником прочностью 65-70 МПа.

Вне зоны влияния очистных работ первый контур расслоений произошел через 20 мин на расстоянии от выработки 1,6 м, через 25 сут на расстоянии 1,8 м и через 3 мес. на расстоянии 2,2 м (рис. 24). Наиболее опасными являются растягивающие напряжения, расположенные перпендикулярно напластованию, превосходящие пределы прочности на контактах и вызывающие отслоение пород с отрывом слоев друг от друга, а затем их обрушение. Процесс расслоения пород происходит под действием касательных напряжений, направленных вдоль напластования, которые вызывают проскальзывание слоев. Величина сцепления на площадках контактного прослойка, сложенного углистым прослоем, при аргиллите составила 0,1, a при песчанике - 0,4 МПа.

На рис. 24 видно, что образовалось три расслоившихся контакта слабых пород (зоны I, II, III). 


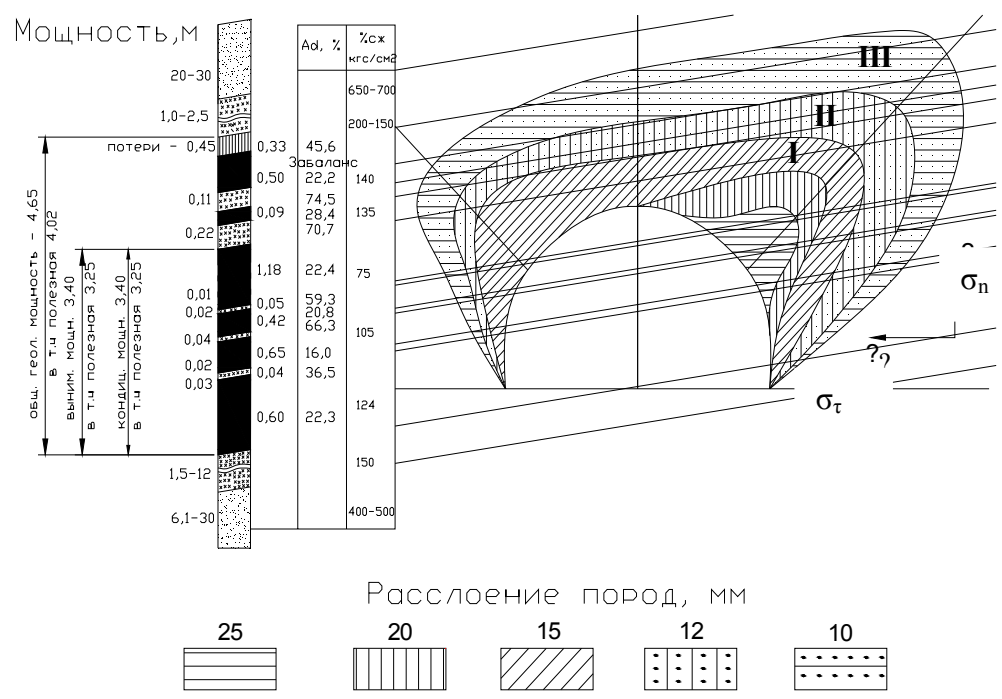

Рис. 24. Зоны расслоения приконтурного массива пород конвейерного штрека 71к 10 -в шахты «Саранская»

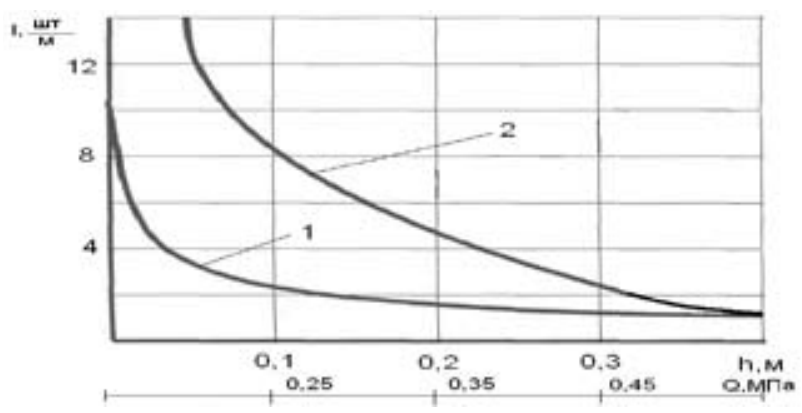

Рис. 25. Зависимость модуля трещиноватости $(I)$ от мощности слоя $(h-1)$ и предела прочности на растяжение $\left(Q_{c}-2\right)$

Обработка экспериментальных данных позволила получить зависимость модуля трещиноватости от мощности слоя и предела его прочности на растяжение (рис. 25).

Для заданных выше условий разработки выполнено аналитическое моделирование методом конечных элементов. На рис. 26 представлены деформационные картины областей с равными продольными напряжениями в вентиляционной выработке с комбинированной крепью (металлорамной и анкерной, сверху по восстанию пласта находится выработанное пространство), где $\kappa_{y}$ - коэффициент усиления.

В выработке, закрепленной комбинированной ограниченно податливой анкерной (в шахматном порядке) и металлорамной крепью (рис. 26,a) без крепи усиления, продольные составляют 300-830 МПа, а в зоне влияния очистных работ с крепью усиления (с коэффициентом усиления $\left.\kappa_{y}=1,5 ; 1,85 ; 2,0\right)$, несмотря на прирост горного давления, они составили 400-600 МПа (рис. 26,б), чем достигается устойчивость контуров выработки. В этом слу- 
a)

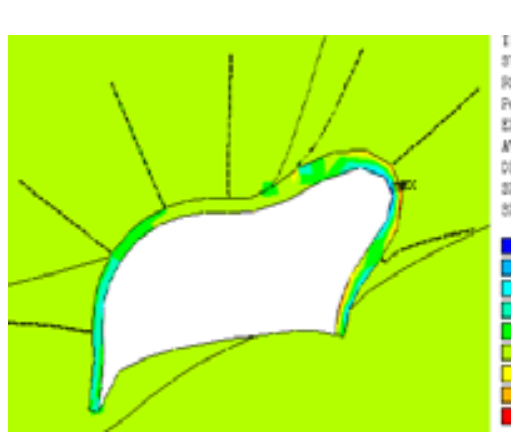

б)

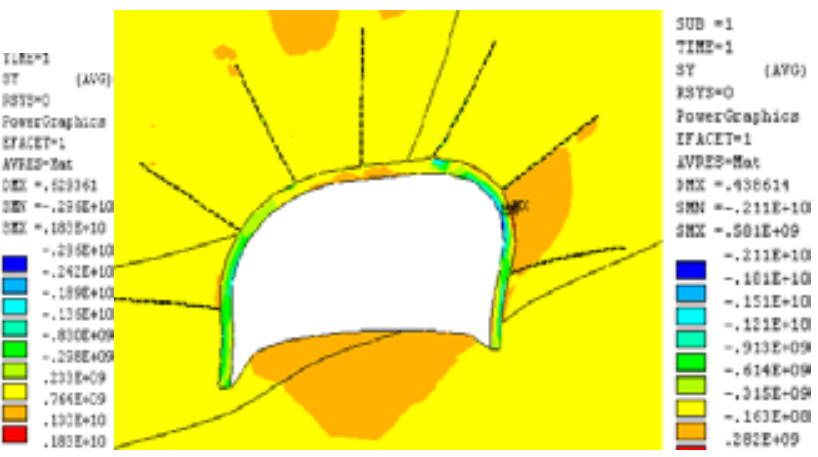

Рис. 26. Деформационные картины областей с равными продольными напряжениями в вентиляционной выработке с комбинированной крепью (металлорамной и анкерной): а - стандартные $\kappa_{y}=1,5$; б - ограниченно податливые $\kappa_{y}=2,0$

чае нагрузка на выработку с использованием ограниченно податливой крепи будет меньше в 1,15 раза.

В зоне влияния очистных работ растет вертикальная составляющая давления из-за пригрузки консолей вышележащих пород и их расслоением, увеличиваются условные зоны неупругих деформаций со смещением пород в кровле выработки на 1,2-1,3 м. Своевременная установка усиливающей крепи позволит уменьшить смещения приконтурных пород и сохранить выработку в эксплуатационном состоянии.

В данной выработке для сравнения были исследованы режимы работы комбинированной крепи с металлорамной крепью со стандартными и ограниченно податливыми анкерами в зоне влияния очистных работ (табл.).

Статистическая обработка результатов эксперимента при возведении податливых анкеров при устойчивых породах кровли в зоне влияния очистных работ с крепью усиления (стоек под профили) позволила выявить эмпирическую зависимость устойчивости выработки от влияющих факторов (при коэффициенте корреляции $R^{2}=0,99$ ):

$$
\mathrm{Y}_{\mathrm{K}}=4,84-0,08 \mathrm{~A}_{\mathrm{H}}-0,08 \mathrm{~T}_{\mathrm{c}}-0,77 \mathrm{~L}_{\mathrm{a}}+0,72 \mathrm{D}_{\mathrm{y}}-0,01 \mathrm{P}_{\mathrm{c}}-0,04 \mathrm{C}_{\mathrm{K}}-0,51 \mathrm{P}_{\mathrm{M}} .
$$

По критерию Стьюдента существенна зависимость $V_{k}$ от $A_{H}, D_{y}, C_{k}$, несущественна - от $T_{c}$ и $L_{a}$ и минимальна - от $P_{c}$ и $P_{\mu}$.

Непосредственно под лавой в зоне опорного давления устанавливалась крепь усиления из одного-двух рядов клиновых или гидростоек под две нитки профилей. В этих условиях увеличение расчетного сопротивления анкерной крепи (за счет узла податливости) с 60 до 140 кПа

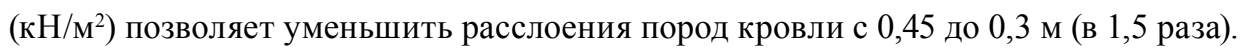

При малом количестве расслоившихся контактов (до трех штук) слабых пород для обеспечения удовлетворительного состояния пород кровли расчетное сопротивление анкерной крепи должно составлять 140-200 кПа при длине анкеров до 2,4 м. Проведенные испытания на шахте «Саранская» позволили установить, что при устойчивой кровле (прочность пород на одноосное сжатие $R_{c}$ более 60-80 МПа) плотность установки составляет 1 анкер/м² (см. табл.). 
Таблица. Устойчивость контуров конвейерного штрека $71 \kappa_{10}$-в шахты «Саранская» в зависимости от технологических параметров крепления

\begin{tabular}{|c|c|c|c|c|c|c|c|}
\hline$A_{\mu}, \mathrm{\kappa H}$ & $T_{\mathrm{c}}$ & $L_{a}, \mathrm{M}$ & $D_{y}$, шт/м ${ }^{2}$ & $P_{c}$, кПа & $C_{\kappa}$, мм & $P_{M}, \mathrm{M}$ & $y_{\kappa}^{*}$ \\
\hline \multicolumn{8}{|c|}{ Анкеры без податливости } \\
\hline 12 & 1 & 1,8 & 1,0 & 70 & 590 & 0,9 & 0,1 \\
\hline 12 & 1 & 2,0 & 0,93 & 100 & 540 & 0,91 & 0,1 \\
\hline 12 & 1 & 2,2 & 1,2 & 155 & 460 & 0,92 & 0,5 \\
\hline 12 & 1 & 2,0 & 0,9 & 170 & 435 & 0,93 & 0,6 \\
\hline 12 & 2 & 2,2 & 1,2 & 190 & 390 & 0,95 & 0,85 \\
\hline \multicolumn{8}{|c|}{ Ограниченно податливые анкеры } \\
\hline 15 & 1 & 2,2 & 1,28 & 235 & 350 & 0,4 & 0,9 \\
\hline 15 & 1 & 2,4 & 1,2 & 275 & 300 & 0,4 & 0,91 \\
\hline 15 & 2 & 2,4 & 1,28 & 295 & 295 & 0,38 & 0,92 \\
\hline 15 & 2 & 2,4 & 1,28 & 240 & 285 & 0,35 & 0,93 \\
\hline 15 & 2 & 2,4 & 1,28 & 375 & 260 & 0,3 & 0,95 \\
\hline
\end{tabular}

* $A_{н}$ - несущая способность анкерной крепи, т; $T_{c}$ - количество рядов крепи усиления из ремонтин; $L_{a}-$ длина анкеров, м; $D_{y}$ - плотность установки анкеров, анкер/м²; $P_{c}$ - суммарное сопротивление рамной, анкерной и крепи усиления; $C_{\kappa}-$ смещения кровли, мм; $P_{\mu}$ - расслоения горного массива в зоне установки анкерной крепи, м.

Дальнейшее увеличение длины, прочности на разрыв стержней анкерной крепи, плотности ее установки в таких условиях технически и экономически нецелесообразно, так как не приводит к заметному уменьшению смещений пород кровли и ее состояния, только снижает темпы проведения горных выработок.

Результаты выполненных аналитических и экспериментальных исследований показали их относительную сходимость по деформационным характеристикам. Таким образом, для более полного использования несущей способности комбинированной крепи и повышения устойчивости выработки в зоне опорного давления целесообразно применение ограниченно податливой с переводом в жесткий режим эксплуатации анкерной крепи. Анкеры связывают отдельные малосвязанные слои пород в единую грузонесущую конструкцию составной плиты, тем самым увеличивают сцепление и трение между слоями. За счет натяжения анкеров между слоями пород возникают дополнительные силы трения. При этом устойчивость составной плиты, стянутой поперек слоев анкерами, приближается к устойчивости монолитной толщи пород.

Кровля, анкерированная комбинированной податливой анкерно-рамной крепью, работает в трех циклах эксплуатации: в жестком режиме, в режиме податливости с расслоением и сдвижением породных напластований и в режиме длительной устойчивости с постоянной несущей способностью, обусловленной подпором анкерной и рамной крепей и самозаклинивания породных блоков. При жесткой крепи возрастание нагрузки влечет пропорциональный рост касательных напряжений, а при податливой - их относительную стабильность.

\section{Выводы}

Исследован механизм деформирования, сдвижения и обрушения пород в структурно нарушенном неоднородном горном массиве, его влияние на функционирование подсистемы «гор- 
нопроходческие работы» с применением компьютерных программ для оценки НДС породного массива вокруг горных выработок.

Проведенные сравнительные исследования проявлений горного давления в выемочных выработках с различными видами крепления позволили установить характер их эксплуатационной работоспособности. При этом деформации выработок, комбинированной анкернорамной крепью, меньше в 3-4 раза, чем при металлорамной крепи.

Определено влияние горно-геологических и горно-технических факторов на образование зон неупругих деформаций во вмещающих породах вокруг выемочных выработок. Исследована устойчивость контуров подготовительных выработок с учетом их напряженнодеформированного состояния в зависимости от горно-геологических и технологических факторов факторов с использованием метода конечных элементов. Определены границы области неупругих деформаций методом последовательных нагружений. Рассмотрены параметры деформирования боковых пород горной выработки от угла падения пласта и глубины анкерования.

При малой глубине разработки (400 м) минимальные напряжения присущи прямоугольной форме сечения выработки. Для среднего уровня глубин разработки (600-700 м) вполне приемлема арочная форма поперечного сечения выработки. Изменение угла наклона в диапазоне от 0 до $30^{\circ}$ не приводит к существенному изменению нагрузочной картины. Характеристики управляемости вмещающих пород проявляются в большей степени по приближенности вновь образованных трещин к контуру выработки лишь при трудноуправляемой кровле (в 5 раз) и находятся на расстоянии от сечения выработки, не превышающем 0,5 м. С ростом глубины разработки (с 600 до 1000 м) трещинообразование возрастает в 1,5 раза. При этом увеличение диаметра шпуров (до 0,05 м) негативно сказывается на возникающих напряжениях и приводит к их двукратному росту на всем диапазоне. Первые эпюры условных зон неупругих деформаций от контура выработки располагаются на расстоянии 1,6-2,0 м.

Вентиляционная выработка с анкерным креплением даже до подхода лавы не выдерживает действующего давления и требует установки крепи усиления. Конвейерная выработка, закрепленная анкерной крепью, до подхода лавы сохраняет устойчивость. С ростом длины анкера (с 1,8 до 2,2 м) и его диаметра (0,02-0,024 м) более значительны продольные напряжения (55-60 Па) с тенденцией их повышения.

Конструкция крепи должна предотвращать рост зон разрушения (неупругих деформаций) в приконтурной части боковых пород при их обнажении. При этом по изолиниям долговечности определяются зоны разрушения в краевой части выработки в разные промежутки времени с момента обнажения.

Для ограниченно податливой крепи характерна упруго-пластическая модель с разупрочнением. Установка такой анкерной крепи в слабых породах приведет к срабатыванию узла податливости при образовании ближайшей по времени зоны разрушения. Образующийся свод-мост перераспределяет воздействие вертикального горного давления от сдвижения вышележащих пород на пяты свода - прилегающие боковые породы, что останавливает процесс формирования вертикальной пригрузки от зон разрушения на крепь выработки. Эффект управления породами кровли состоит в том, что в кровле выработки образуется грузонесущая плита с прочными связями между блоками и повышенной устойчивостью породных обнаже- 
ний, препятствуя образованию трещин расслоения пород по напластованию (трещин горного давления) и кососекущих технологических трещин. Ограниченно податливая анкерная система крепит породу, ограничивая движение кровли, и позволяет горизонтальному напряжению удерживать породы кровли на месте, не давая им обрушиться.

\section{Список литературы}

[1] Цай Б.Н. Термоактивационная природа прочности горных пород. Караганда: КарГТУ, 2007. $204 \mathrm{c}$. 